\title{
The Effect of the Duration of Playing Online Games on Students' Depression Level
}

\author{
$1^{\text {st }}$ Elis Noviati \\ STIKes Muhammadiyah Ciamis \\ Ciamis, Indonesia \\ *elisnoviati@gmail.com \\ $4^{\text {th }}$ Ima Sukmawati \\ STIKes Muhammadiyah Ciamis \\ Ciamis, Indonesia
}

\author{
$2^{\text {nd }}$ Rudi Kurniawan \\ STIKes Muhammadiyah Ciamis \\ Ciamis, Indonesia \\ $5^{\text {th }}$ Lilis Lismayanti \\ STIKes Muhammadiyah Ciamis \\ Ciamis, Indonesia
}

\author{
$3^{\text {rd }}$ Rudi Herdiana \\ STIKes Muhammadiyah Ciamis \\ Ciamis, Indonesia
}

\begin{abstract}
The online game is very popular with the community especially teenagers or early adulthood because at this time humans are in the search for their undergraduate program, where they are very easy to accept new phenomena from outside. himself or the environment. Online game users often play excessively with a long duration of time, causing various negative impacts, one of which is depression. The purpose of this study was to determine the effect of the duration of playing online games with the level of depression of the S1 Nursing Study Program Students of STIKes Muhammadiyah Ciamis. This study is an analytic survey with a cross-sectional approach. The number of research samples was 78 subjects, all students of the Nursing Study Program of STIKes Muhammadiyah Ciamis who played online games and included the inclusion and exclusion criteria. Analysis of data using Spearman ranks statistical tests. The results showed that there was an influence of the duration of playing online games on the level of depression with a Sig value of $0.01<0.05$ and a correlation coefficient of 0.383 . The conclusion that there is a weak influence of the duration of playing online games on the level of depression of the S1 Nursing Study Program students of STIKes Muhammadiyah Ciamis.
\end{abstract}

\section{Keywords-Play Online Games, Students, Depression}

\section{INTRODUCTION}

Online games are the result of technological advances where online games can be accessed by many players and the machines used by players are connected by a network generally the network used to play is the Internet. A large number of game enthusiasts can be caused by the better quality and quality of online games that exist today [1].

According to the Indonesian Internet Service Providers Association or APJII [2], internet usage has reached 143.26 million of the total Indonesian population of 262 million people. APJII also shows data that $74.23 \%$ of internet users are aged 19-34 years. That means most internet users are among teenagers and early adults. Internet usage for online games alone reaches $54.13 \%$. This data increased compared to data released in 2016 which amounted to $40.33 \%$.

Online games are very popular with internet users because online games not only provide entertainment for their users but also provide challenges that make it interesting to complete them or reach certain targets. Individuals often do not take into account time to achieve satisfaction in playing online games. This makes users online games not only connoisseurs but can become addicts [3].

The bad effects of online games often approach adolescents, because adolescence is a transition from childhood to adulthood. As in Erikson's psychosocial development theory which states "that adolescents are in the phase of searching for self-identity where adolescents spend more time with peers than with parents and family. This allows teens to accept phenomena that occur from the surrounding environment or their friends. "Just like online games, teenagers can be influenced by the environment or their friends to play online games and may be affected by the addiction of online games [4].

The inability to control themselves in playing online games when a teenager is not impossible also has an impact on the time when someone stepped into adulthood, especially early adulthood as data shown by APJII which shows the largest number of internet users in Indonesia, namely adolescents and early adults.

The impact of online games can indirectly build a bad personality, causing chaos in the lifestyle of its users. according to health institutions in the American, American Medical Associations or AMA [5] on Emotional and Behavioral Effects of Video Games and Internet Overuse, states emotionally someone with an addiction to online games can be disrupted. For example, he suddenly pushed his friend, suddenly hit and it has become one of the addictions of online gaming also affect emotionally. Even a 15-year-old teenager Russian reported by Tribunnews.com from The Sun committed suicide because of losing the game. This incident shows that online games can cause emotions out of control and even cause depression when users cannot control themselves.

Depression can be a risk factor for someone becoming an addict online game, but it can also be a result of addiction online gaming. Addiction to online games can cause a person to become isolated and isolated from family and society. The more time you spend playing games, the more isolated you will become. As a result, 
vulnerable to various disorders and mental disorders, one of which is depression. Depression is a mood disorder characterized by loss of energy and interest, feelings of guilt, difficulty concentrating, loss of appetite and thoughts about death and suicide, where these changes almost always lead to interpersonal, social and work disruption.

Research on the relationship between online games and depression in adolescents conducted by [6], with 35 respondents, showed the results that someone with an addiction online gaming had a 1.61 times greater risk of depression than a teen without an addiction online gaming [7].

\section{RESEARCH METHOD}

The design used in this research is the analytic survey with approach cross-sectional. The sampling technique uses purposive sampling and then the distribution of samples is done by technique proportional to the distribution of samples from each level. Data collection was carried out in May 2019 with 78 students of level I, II, III \& IV of S1 Nursing Study Program of STIKes Muhammadiyah Ciamis, who met the research criteria.

The research instrument used was the questionnaire sheet Beck Depression Inventory (BDI) to measure the level of depression, while to measure the duration of playing online games respondents were asked questions about the duration of playing online games per day in hours.

\section{RESEARCH RESULTS}

The distribution of respondents' characteristics includes gender and age.

TABLE 1. FREQUENCY DISTRIBUTION OF STUDENTS WHO PLAY ONLINE GAMES BASED ON GENDER

\begin{tabular}{|c|c|c|c|}
\hline No & Gender & $\mathrm{F}$ & $\%$ \\
\hline 1 & Male & 61 & 78 \\
\hline 2 & Female & 17 & 22 \\
\hline \multicolumn{2}{|c|}{ Total } & 78 & 10 \\
\hline
\end{tabular}

From table 1 it is known that male students dominate users the online game most on their mobile phones namely 61 students $(78 \%)$ compared to female students.
TABLE 2. FREQUENCY DISTRIBUTION OF STUDENTS WHO PLAY ONLINE GAMES BASED ON AGE

\begin{tabular}{|c|c|c|c|}
\hline No & Age (Years) & F & $\%$ \\
\hline 1 & $\leq 18$ & 6 & 8 \\
\hline 2 & $\geq 1917-24$ & 72 & 92 \\
\hline Total & & 78 & 100 \\
\hline
\end{tabular}

Based on table 2 it is known that the age of students who play online games years with the majority in the early adult phase with a percentage $(92 \%)$.

TABLE 3. FREQUENCY DISTRIBUTION OF DURATION OF PLAYING ONLINE GAMES

\begin{tabular}{|c|c|c|c|}
\hline No & Playing duration (Hours) & $\mathrm{F}$ & $\%$ \\
\hline 1 & $<5$ & 42 & 54 \\
\hline 2 & $5-6$ & 20 & 26 \\
\hline 3 & $>6$ & 16 & 20 \\
\hline \multicolumn{2}{|c|}{ Total } & 78 & 100 \\
\hline
\end{tabular}

Based on table 3 it is known that the majority the duration of playing online games for students in the normal category $<5$ hours/day is 42 respondents (54\%). While respondents who are categorized as playing online games excessively 5-6 hours/day or> 6 hours/day are 36 students $(46 \%)$.

TABLE 4. FREQUENCY DISTRIBUTION OF DEPRESSION LEVELS FOR STUDENTS

\begin{tabular}{|c|l|c|c|}
\hline No & Depression Rate (BDI) & F & $\%$ \\
\hline 1 & Minimum Depression & 59 & 76 \\
\hline 2 & Minor Depression & 17 & 22 \\
\hline 3 & Moderate Depression & 2 & 2 \\
\hline 4 & Severe Depression & 0 & 0 \\
\hline & Total & 78 & 100 \\
\hline
\end{tabular}

Based on table 4 know that the majority of depression rates are categorized as minimal depression levels, namely 59 students (76\%), 17 students (22\%) mild depression, 2 students $(2 \%)$ moderate depression and no one has severe depression.

TABLE 5. FREQUENCY DISTRIBUTION OF THE INFLUENCE OF THE DURATION OF PLAYING ONLINE GAMES ON THE LEVEL OF DEPRESSION

\begin{tabular}{|c|c|c|c|c|c|c|c|c|c|c|c|c|}
\hline \multirow{3}{*}{$\begin{array}{c}\text { Duration } \\
\text { (Hour) }\end{array}$} & \multicolumn{8}{|c|}{ Depression Rate (BDI) } & \multirow{2}{*}{\multicolumn{2}{|c|}{ Total }} & \multirow{3}{*}{$\begin{array}{c}p \\
\text { value }\end{array}$} & \multirow{2}{*}{$\begin{array}{l}\text { Correlation } \\
\text { Coefficien }\end{array}$} \\
\hline & \multicolumn{2}{|c|}{ Minimal } & \multicolumn{2}{|c|}{ Mild } & \multicolumn{2}{|c|}{ Moderate } & \multicolumn{2}{|c|}{ Heavy } & & & & \\
\hline & $\mathrm{F}$ & $\%$ & $\mathrm{~F}$ & $\%$ & $\mathrm{~F}$ & $\%$ & $\mathrm{~F}$ & $\%$ & $\mathrm{~F}$ & $\%$ & & \\
\hline$<5$ & 40 & 51 & 2 & 3 & 0 & 0 & 0 & 0 & 42 & 54 & & \\
\hline $5-6$ & 8 & 10 & 12 & 15 & 0 & 0 & 0 & 0 & 20 & 25 & 0,001 & 0,383 \\
\hline$>6$ & 11 & 14 & 3 & 4 & 2 & 3 & 0 & 0 & 16 & 21 & & \\
\hline Total & 59 & 75 & 17 & 22 & 2 & 3 & 0 & 0 & 78 & 100 & & \\
\hline
\end{tabular}

Based on table 5 shows that the majority of the duration of playing online games students the normal category ( $<5$ hours/day) is as many as 42 students and almost all are depressed with a minimum percentage 
(95\%). While 36 students (46\%) play online games excessively with a duration of 5-6 hours/day or> 6 hours/day and $43 \%$ are categorized as having minimal depression, $42 \%$ are experiencing mild depression, then $2 \%$ are categorized as having moderate depression. Statistical test results Spearman Ranks obtained p-value (sig) $<\alpha(0.001<0.05)$, then the hypothesis is accepted (H0 rejected or Ha accepted) and it can be concluded that there is an influence between the intensity of playing online games with the depression level of students in Nursing Undergraduate Study Program Muhammadiyah Ciamis STIKes

\section{DISCUSSION}

\section{A. Univariate analysis overview of the duration of} playing online games

Based on the results of the study table 3 shows that of 78 students almost half the respondents namely 36 students $(46 \%)$ play online games with a duration that is categorized as excessive playing ie 5-6 hours/day or $>6$ hours/day with the longest playing duration which is 10 hours/day. If the average - the duration of playing online games from all respondents is 4.5 hours/day. According to the results of interviews with respondents, it is known that the majority of the duration of playing games they do every day is not always done at one time. And the majority of students mention that they can play online games 2-3 times in one day.

Based on gender, men tend to play a lot of online games excessively with a percentage of $51 \%$ of 61 male respondents. This percentage is higher than the percentage of female respondents, which is only $29 \%$ of 17 female respondents who play online games excessively. The results of this study are in line with research conducted by Puspitosari \& Ananta [7], regarding the relationship between addiction online game and depression, showing that $90.6 \%$ of addicts are online game male. And states that men are more easily addicted to online games compared to women.

Based on age, the results of data analysis showed $50 \%$ of all respondents classified as teenagers, playing online games with a range of 5-6 hours or categorized as playing in excessive duration. Whereas the early adult respondents who were categorized as playing online games excessively were as much as $46 \%$ of the total number of early adult respondents. That means teenagers have more percentage in the category of playing online games excessively compared to early adulthood.

\section{B. Description of depression levels of undergraduate students}

Based on the results of table 4 research, it is known that the majority of depression levels of S1 Nursing Study Program students of Muhammadiyah Ciamis STIKes are categorized as minimal depression levels, namely 59 students $(76 \%), 17$ students $(22 \%)$ are categorized as experiencing mild depression, students (2\%) are categorized as experiencing moderate depression and no one has severe depression. From the results of the questionnaire analysis on students categorized as experiencing minimal depression most experienced symptoms such as difficulty initiating activities, lack of confidence, often delaying decisions, easy to feel annoyed, easy to feel tired and feel difficult to rest or not sleep soundly. These symptoms often appear in students who are categorized as experiencing minimal depression.

From the results of the study, there were no respondents who experienced severe depression and a few were experiencing moderate depression, which was only $3 \%$ of the total number of respondents. This is because the average age of the respondent is early adulthood where in this phase a person starts to have responsibilities as an early adult, so that he can hold back and choose priorities that are more beneficial for the sake of the future compared to things that are less useful when playing online games excessively who do not know the time and can have psychological effects, especially on the level of depression of users.

Hurlock [8], states the task at early adulthood is the level of mastery of the tasks in reaching the peak of their success. In early adulthood, many new problems must be faced by someone whose problem is different from problems that have been experienced before. From an emotional standpoint, early adulthood experiences emotional tension and experiences social alienation. Social alienation is identified with a competitive spirit and a strong desire to advance in a career, so hospitality in adolescence is replaced by competition in adult society. At this time also is a time of making new commitments to his lifestyle from dependence on parents to being mature and independent.

\section{Bivariate Analysis}

Based on the results of Table 5, it is known that from 78 students the majority of the duration of playing online games undergraduate students of the Nursing Study Program of STIKes Muhammadiyah Ciamis were in the normal category of 42 students and almost all were depressed with a minimum percentage $(95 \%)$. While 36 students $(46 \%)$ play online games excessively with a duration of 5-6 hours/day or $>6$ hours/day and $43 \%$ are categorized as having minimal depression, $42 \%$ are experiencing mild depression, then $2 \%$ are categorized as having moderate depression. It can be said that students with mild or moderate depression show duration of playing online games excessive5-6 hours/day or> 6 hours/day with a percentage of $90 \%$. And the higher the level of depression, the longer the duration of playing online games.

Statistical test results Spearman Ranks obtained $\mathrm{p}$ (sig) $<\alpha(0.001<0.05)$, then the hypothesis is accepted (H0 rejected or Ha accepted) with a correlation value of 0.383 and it can be concluded that there is a weak influence between the intensity of playing online games with the depression level of the Muhammadiyah Ciamis Undergraduate Nursing Undergraduate Program Study Program. And the longer the duration of students playing online games, the more severe the level of depression they experience.

These results are in line with the results of Mohammad's research [9], about the relationship of the 
intensity of playing online games to the occurrence of stress, depression, social phobia, sleep disorders, and aggressive behavior. From the depression, variable shows the statistical results Wilcoxon Signed Ranks Test obtained p-value (sig) $<\alpha(0,0001<0.05)$, then the hypothesis is accepted (H0 rejected or Ha accepted) and it can be concluded that there is a relationship between the intensity of playing online games with the onset of depression.

According to the interview, a few respondents found the reason most students of Muhammadiyah S1 Nursing STIKesCiamis play online games namely your spare time when no activity or because the game is exciting to keep playing so that students are constantly motivated to play the game online. When a student cannot control himself in playing the game it will be addictive with one of the symptoms seen from the duration of playing the game. When someone has been addicted and cannot control themselves, the negative impact of online games will appear one of which is depression. This is evidenced by the results of research from 19 students who were categorized as experiencing mild or moderate depression as many as 17 students (90\%) played online games excessively ie 5-6 hours/day or> 6 hours/day.

\section{CONCLUSION}

Based on the results of research on the effect of the duration of playing online games on the level of depression undergraduate students of the Nursing study program STIKes Muhammadiyah Ciamis can be concluded as follows: Duration of playing online games with excessive play category 5-6 hours/day or> 6 hours/day is 36 students $(46 \%)$ with the longest playing duration which is 10 hours/day. If the average - the duration of playing online games from all respondents is 4.5 hours/day, the majority of depressive students in the Nursing undergraduate program at the Muhammadiyah Ciamis STIKes are categorized as a minimum level of depression, which is 59 students (76\%). With most experiencing symptoms such as difficulty starting activities, lack of confidence, often delaying decisions, easy to feel annoyed, easy to feel tired and feel difficult to rest or not sleep soundly, there is an influence of the duration of playing online games on the level of depression of the S1 Nursing Study Program students of STIKes Muhammadiyah Ciamis with a Sig value of 0.001 $<0.05$. And the longer the duration of students playing online games, the more severe the level of depression they experience, The correlation value between the duration of playing online games and the level of depression of the S1 Nursing Study Program students of STIKes Muhammadiyah Ciamis is 0.383 . It means that it has a weak correlation.

\section{REFERENCES}

[1] Dinata, O, 2017, Hubungan Kecanduan Game Online Clash Of Clans Terhadap Prilaku Sosial. Jom FISIP, 4(2), 1-15.

[2] Bastian, H., \& Khamadin. (2016). Dampak Digital Game Terhadap Perkembangan Sosial Budaya Masyarakat. Andharupa, 2(1), 3344.

[3] Ratnasari, C. D, 2016, Gambaran Kualitas Tidur pada Komunitas Game Online Mahasiswa Teknik Elektro Universitas Diponegoro.
[4] Febriandari, D., Nauli, F. A., \& Rahmalia, S, 2016, Hubungan Kecanduan Bermain Game Online terhadap Identitas Diri Remaja. Jurnal Keperawtan Jiwa, 4(1), 10.

[5] Nurazmi, A, Elita, V, \& Dewi, W, N, 2017, Hubungan Kecanduan Bermain Game Online Terhadap Regulasi Emosi Pada Remaja, $555-562$.

[6] Ariani, S, 2012, Hubungan kecanduan online game dengan depresi pada remaja laki-laki pengunjung game center di Kelurahan Jebres.

[7] Puspitosari, W. A., \& Ananta, L, 2005, Hubungan antara kecanduan online game dengan depresi Correlation between Online Game Addiction with Depression, 50-56.

[8] Hurlock, E. B, 1980, Psikologi Perkembangan. Jakarta: PT. Gelora Aksara Pratama.

[9] Mohammad, H, 2017, Hubungan intensitas bermain game online terhadap terjadinya stres, depresi , social phobia, gangguan tidur serta perilaku agresif. 